\title{
A Urinary Diabetogenic Peptide in Proteinuric Diabetic Patients
}

\author{
By Lawrence H. Louis and Jerome W. Conn
}

\begin{abstract}
A polypeptide exhibiting diabetogenic and anti-insulin properties has been isolated from the urine of 33 of the 35 proteinuric diabetic patients. This material could not be found in the urine of 34 normal subjects and 32 diabetic patients without proteinuria. It was, however, detected chemically in one of seven nondiabetic patients with proteinuria, but the amount present was insufficient for biological testing. This polypeptide closely resembles, in physiochemical properties, that obtained from patients
\end{abstract}

with lipoatrophic diabetes, as well as that isolated from the adenohypophyses of beef, sheep, and swine. The isoelectric point of the active polypeptide from all the above sources is approximately $\mathrm{pH}$ 4.1. In one diabetic subject who underwent hypophysectomy, this material disappeared from the urine following the operation. It is suggested that the source of the active principle isolated from the urine of diabetic patients with proteinuria is probably the pituitary gland. (Metabolism 18: No. 7, July, 556-563, 1969)

$\mathbf{I}^{\mathrm{N}}$ N 1963 WE REPORTED that the urine of patients with lipoatrophic diabetes contains a diabetogenic polypeptide. ${ }^{1}$ This has recently been confirmed by others. ${ }^{2}$ We demonstrated that the peptide was capable of impairing glucose tolerance and of inducing insulin resistance when administered either to dogs or humans. The present study was designed to explore the possibility that a similar substance might be found in the urine of diabetic patients without lipodystrophy since a chance observation had disclosed its presence in an obese, maturity-onset diabetic. ${ }^{1}$ Freshly collected urine samples from 67 diabetic patients and 34 healthy subjects have been studied. The diabetogenic peptide was found in the urine of 33 of 35 diabetics with proteinuria but it was absent in all of 32 diabetics without proteinuria, as well as in the normal subjects. Seven additional subjects with proteinuria but without diabetes were studied. One of them exhibited a similar urinary material.

\section{Materials and Methods}

Collection and preservation of urine samples were the same as previously described.1 Clinical information on the proteinuric diabetic subjects studied are shown in Table 1. Our

From the Department of Internal Medicine, Division of Endocrinology and Metabolism and the Metabolism Research Unit, University of Michigan Medical School, Ann Arbor, Mich.

This work was supported by Grant AM-06665, National Institute of Arthritis and Metabolic Diseases, United States Public Health Service.

Received for publication March 10, 1969.

LAwrence H. Louts, Sc.D.: Associate Professor of Biological Chemistry, Department of Internal Medicine, University of Michigan Medical School, Ann Arbor, Mich. Јевоме W. Cons, M.D.: L. H. Newburgh University Professor of Internal Medicine; Head, Division of Endocrinology and Metabolism; Director, Metabolism Research Unit, University of Michigan Medical School, Ann Arbor, Mich. 


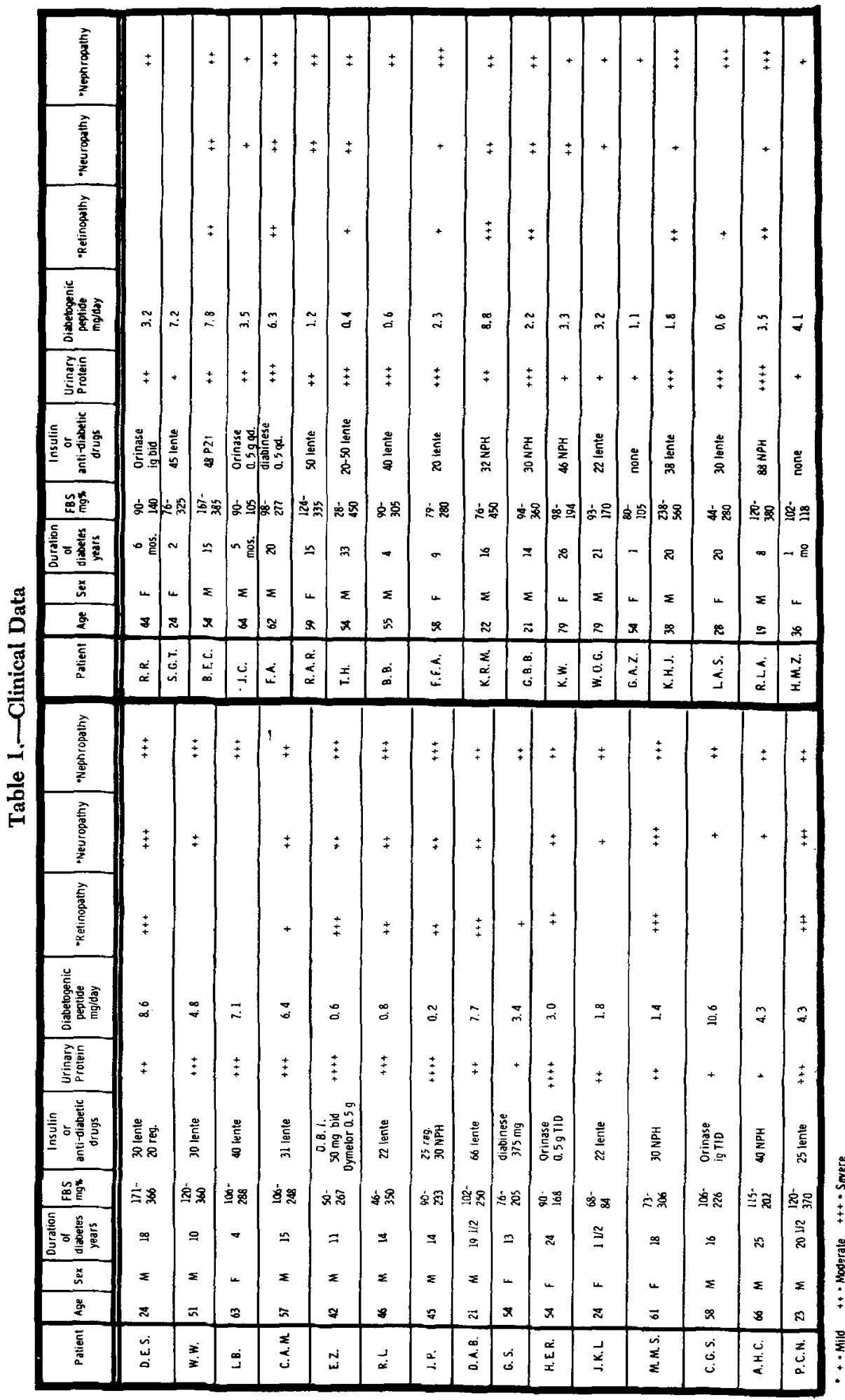




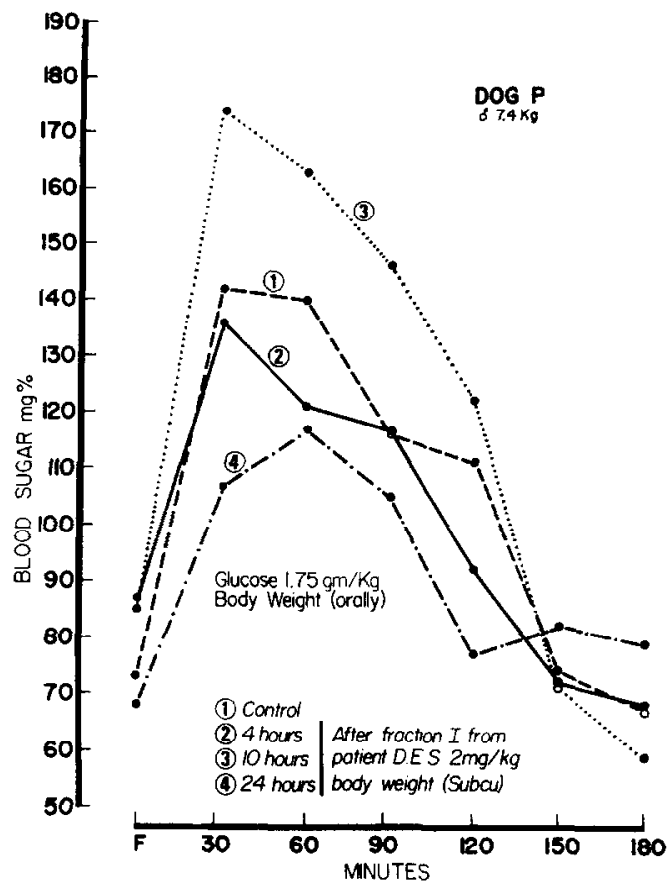

Fig. 1

more recent procedure for the isolation of the diabetogenic polypeptide (fraction I) from urine was employed. ${ }^{3}$

Maintenance and preparation of dogs for glucose and insulin tolerance tests have been previously described. 6,7 In the present studies, two well-trained dogs were employed. However, because of the scarcity of the purified material, most of the tests were done on a small animal (Dog P, 7.4 Kg.). The assay procedure consisted of (a) a control glucose tolerance test done on day 1 , and (b) an injection of the substance 10 hours before the second glucose tolerance test which was done on day 2. An interval of at least 13 dlays elapsed before the procedure was repeated in the same animal with the isolated peptide from another patient.

Blood glucose was measured by the Somugyi-Nelsun prucedure. ${ }^{4}$ Disc electrophoresis was performed in a Model 6 apparatus ${ }^{*}$ with a single bath assembly. The power source was Model 200." Analyses were carried out according to the procedure of Ornstein and Davis. ${ }^{5}$

Electrophoresis was carried out at room temperature at at current of 4 mat per tube for 30 minutes. Polypeptide samples used were $60-100 \mu \mathrm{g}$. per tube. The buffer was of $\mathrm{pH} 8.3$. Destaining was performed at a current of 12,5 ma per tube for 60 minutes.

\section{Results}

An effort to determine the time of maximal biological effect was made by carrying out glucose tolerance tests 4 hours, 10 hours and 24 hours after an injection of the peptide ( $2 \mathrm{mg}$. per kilogram of dog body weight) from patient D.E.S. The results are presented in Fig. 1. In Dog $P$, it appears that the greatest effect occurred 10 hours after injection. Subsequently, all tests were done 10 hours after administration of the peptide. Table 2 shows the effect

\footnotetext{
${ }^{\circ}$ Canal Industrial Corp., Rockville, Md.
} 
Table 2.-Effect of Urinary Polypeptide (Fraction 1) on Glucose Tolerance*

\begin{tabular}{|c|c|c|c|c|c|c|c|c|}
\hline Patient & $\begin{array}{l}\text { Polypeptide } \\
\text { mg./Kg. } \\
\text { body wt. }\end{array}$ & $\mathbf{F}$ & $1 / 2$ & 1 & $1 \frac{1 / 2}{2}$ & 2 & $21 / 2$ & 3 \\
\hline & 0 & 73 & 142 & 140 & 116 & 111 & 74 & 67 \\
\hline \multirow[t]{2}{*}{ D.E.S. } & 2 & 85 & 174 & 163 & 146 & 122 & 71 & 59 \\
\hline & 0 & 93 & 154 & 143 & 111 & 75 & 93 & 88 \\
\hline \multirow[t]{2}{*}{ W.W. } & 2 & 95 & 143 & 243 & 237 & 188 & 119 & 87 \\
\hline & 0 & 88 & 124 & 148 & 138 & 81 & 74 & 88 \\
\hline \multirow[t]{2}{*}{ L.B. } & 2 & 93 & 168 & 238 & 175 & 118 & 106 & 86 \\
\hline & 0 & 77 & 138 & 166 & 156 & 80 & 59 & 72 \\
\hline C.A.M. & 2 & 95 & 171 & 197 & 152 & 122 & 83 & 80 \\
\hline E.Z. I & 0 & 84 & 119 & 161 & 122 & 74 & 72 & 73 \\
\hline R.L. & 1.65 & 104 & 196 & 250 & 166 & 124 & 96 & 99 \\
\hline J.P. & 0 & 84 & 139 & 128 & 118 & 67 & 71 & 89 \\
\hline \multirow[t]{3}{*}{ D.A.B. } & 2 & 94 & 144 & 238 & 285 & 234 & 199 & 131 \\
\hline & 0 & 67 & 102 & 132 & 126 & 74 & 62 & 60 \\
\hline & 0 & 89 & 123 & 133 & 91 & 62 & 78 & 81 \\
\hline \multirow[t]{2}{*}{ G.S. } & 2 & 99 & 178 & 229 & 193 & 143 & 93 & 66 \\
\hline & 0 & 78 & 125 & 151 & 117 & 66 & 74 & 81 \\
\hline \multirow[t]{2}{*}{ H.E.R. } & 2 & 98 & 177 & 235 & 217 & 118 & 86 & 76 \\
\hline & $\mathbf{0}$ & 83 & 130 & 156 & 122 & 104 & 60 & 63 \\
\hline \multirow[t]{2}{*}{ J.K.L. } & 2 & 78 & 157 & 182 & 165 & 118 & 76 & 61 \\
\hline & 0 & 75 & 122 & 117 & 109 & 62 & 76 & 78 \\
\hline \multirow[t]{2}{*}{ M.M.S. } & 2 & 86 & 115 & 148 & 176 & 160 & 173 & 142 \\
\hline & 0 & 77 & 96 & 101 & 80 & 88 & 62 & 60 \\
\hline \multirow[t]{3}{*}{ C.G.S. } & 2 & 88 & 146 & 193 & 192 & 211 & 165 & 118 \\
\hline & 0 & 74 & 118 & 115 & 109 & 98 & 51 & 71 \\
\hline & $\begin{array}{c}\mathrm{pH} 3.5-3.6 \\
\text { material }\end{array}$ & & & & & & & \\
\hline A.H.C. & 2 & 73 & 115 & 137 & 86 & 83 & 65 & 76 \\
\hline \multirow[t]{2}{*}{ A.H.C. } & 2 & 76 & 131 & 187 & 226 & 204 & 177 & 96 \\
\hline & 0 & 72 & 103 & 100 & 87 & 53 & 61 & 66 \\
\hline \multirow[t]{2}{*}{ P.C.N. } & 2 & 77 & 99 & 140 & 126 & 108 & 53 & 58 \\
\hline & 0 & 56 & 121 & 161 & 105 & 66 & 51 & 60 \\
\hline \multirow[t]{2}{*}{ R.R. } & 2 & 71 & 93 & 160 & 201 & 192 & 172 & 105 \\
\hline & 0 & 70 & 105 & 92 & 82 & 87 & 60 & 68 \\
\hline \multirow[t]{3}{*}{ S.G.T. } & 2 & 71 & 124 & 168 & 198 & 159 & 96 & 44 \\
\hline & 0 & 89 & 104 & 141 & 129 & 110 & 51 & 81 \\
\hline & o & 64 & 113 & 138 & 120 & 51 & 62 & 67 \\
\hline \multirow[t]{2}{*}{ B.E.C. } & 2 & 86 & 152 & 193 & 205 & 172 & 95 & 76 \\
\hline & 0 & 68 & 105 & 185 & 60 & 59 & - & 63 \\
\hline \multirow[t]{2}{*}{ J.C. } & 2 & 63 & 151 & 273 & 180 & 95 & 64 & 65 \\
\hline & 0 & 77 & 133 & 167 & 113 & 60 & 62 & 65 \\
\hline F.A. & 2 & 75 & 175 & 233 & 206 & 111 & 63 & 69 \\
\hline R.A.R. ) & 0 & 66 & 132 & 153 & 122 & 66 & 60 & 75 \\
\hline T.H. & 2 & 72 & 128 & 179 & 164 & 132 & 67 & 66 \\
\hline B.B. & 0 & 86 & 115 & 141 & 111 & 83 & 50 & 66 \\
\hline \multirow[t]{2}{*}{ F.A.A. } & 2 & 81 & 116 & 144 & 174 & 135 & 94 & 75 \\
\hline & 0 & 62 & 104 & 168 & 104 & 79 & 65 & 58 \\
\hline \multirow[t]{2}{*}{ K.R.M. } & 2 & 61 & 113 & 151 & 183 & 174 & 133 & 105 \\
\hline & 0 & 60 & 114 & 154 & 103 & 109 & 68 & 57 \\
\hline
\end{tabular}

- Dog P, $7.4 \mathrm{Kg}$; glucose $1.75 \mathrm{Gm} . / \mathrm{Kg}$. body weight (orally). 
Table 2.-continued

\begin{tabular}{|c|c|c|c|c|c|c|c|c|}
\hline Patient & $\begin{array}{l}\text { Polypeptide } \\
\text { mg./Kg. } \\
\text { body wt. }\end{array}$ & $\mathrm{F}$ & $1 / 2$ & 1 & $1 \frac{11 / 2}{2}$ & 2 & $21 / 2$ & 3 \\
\hline \multirow[t]{3}{*}{ G.B.B. } & 2 & - & 107 & 167 & 145 & 101 & 85 & 63 \\
\hline & 0 & 68 & 112 & 162 & 85 & 67 & 63 & 69 \\
\hline & 0 & 86 & 115 & 141 & 111 & 83 & 50 & 66 \\
\hline \multirow[t]{2}{*}{ K.W. } & 2 & 80 & 125 & 177 & 183 & 173 & 152 & 120 \\
\hline & 0 & 73 & 115 & 146 & 111 & 73 & 63 & 64 \\
\hline W.O.G. & 2 & 75 & 126 & 167 & 176 & 142 & 91 & 55 \\
\hline G.A.Z. ) & 0 & 75 & 142 & 175 & 136 & 86 & 59 & 68 \\
\hline K.H.J. & 0 & 73 & 108 & 107 & 102 & 81 & 73 & 66 \\
\hline \multirow{2}{*}{ L.A.S. | } & 1.47 & 84 & 137 & 184 & 159 & 154 & 122 & 88 \\
\hline & 0 & 82 & 123 & 162 & 158 & 102 & 86 & 98 \\
\hline \multirow[t]{2}{*}{ R.L.A. } & 2 & 79 & 105 & 165 & 176 & 149 & 85 & 74 \\
\hline & 0 & 72 & 106 & 149 & 145 & 75 & 58 & 60 \\
\hline \multirow[t]{2}{*}{ H.M.Z. } & 2 & 77 & 144 & 172 & 163 & 109 & 70 & 66 \\
\hline & 0 & 77 & 105 & 108 & 102 & 85 & 85 & 72 \\
\hline
\end{tabular}

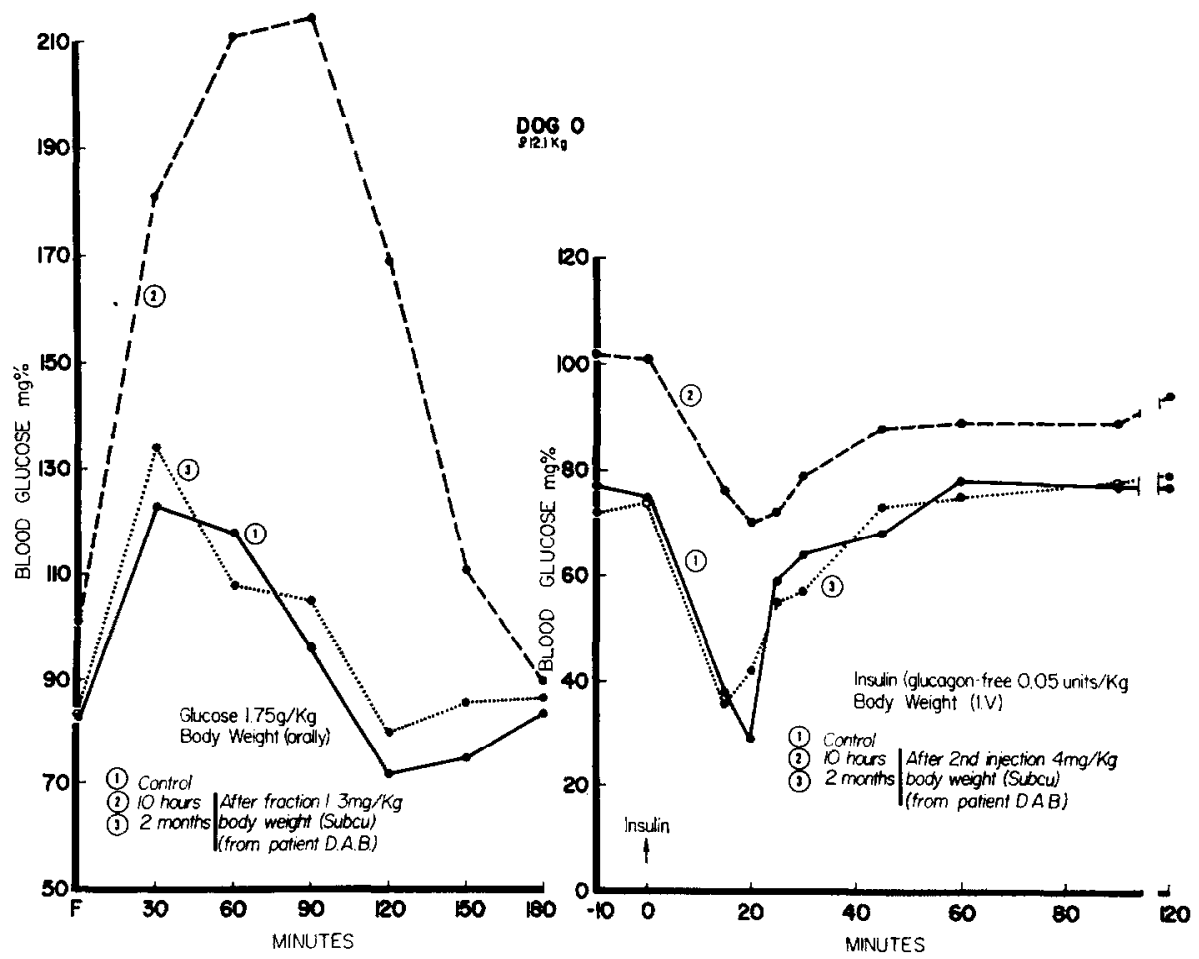

Fig. 2 


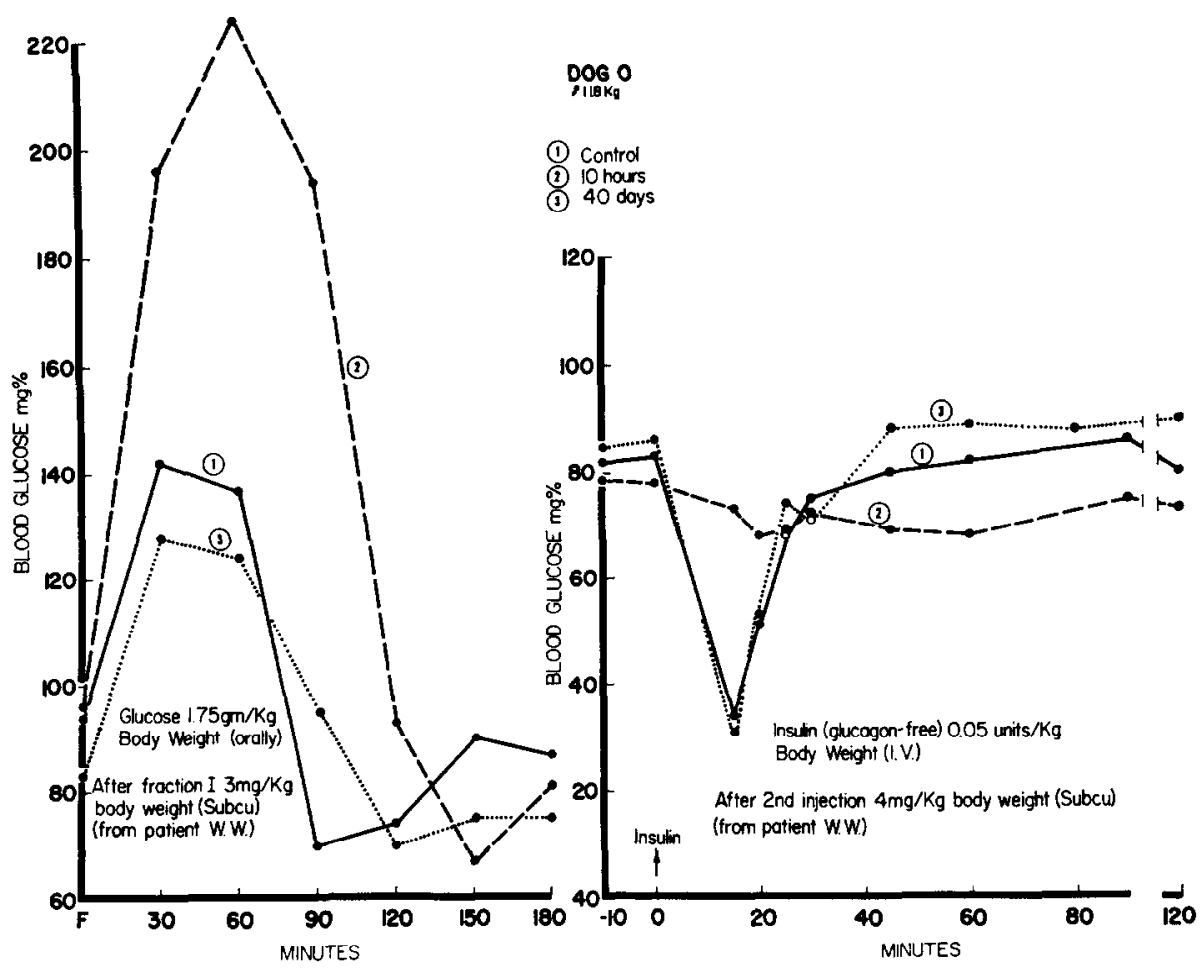

Fig. 3

upon glucose tolerance of the polypeptide (fraction 1) extracted from the urine of each of the 33 diabetic proteinuric patients in which it was found.

Reduced glucose tolerance and insulin resistance induced by the polypeptide from patients W.W. and D.A.B. were demonstrated in another animal as well ( $\operatorname{Dog} O)$. The procedure for these tests was the same as previously described. ${ }^{7}$ Figures 2 and 3 show the results. Of interest is the fact that the peptide found in patient D.A.B. was no longer present after he had undergone surgical hypophysectomy.

Elemental analysis of the diabetogenic polypeptide from patient W.W. shows the following: C 48.14 per cent, $\mathrm{H} 6.89$ per cent, N 14.68 per cent, and S 1.49 per cent. These values are almost the same as those obtained upon the peptide isolated from the urine of patients with lipoatrophic diabetes. ${ }^{3}$

Figure 4 shows the polyacrylamide gel electrophoretic patterns of fraction 1 from a lipoatrophic diabetic (pattern 3 ) and from 3 diabetics with proteinuria (patterns 4,5 and 6). For comparison (Fig. 5) disc electrophoresis was also performed on fraction 1 isolated from bovine (pattern 7) and human (pattern 8) pituitary glands. Further purification of these fractions by Sephadex column chromatography is now in progress.

\section{Discussion}

Since our report ${ }^{1}$ on the isolation of a diabetogenic polypeptide from the urine of patients with lipoatrophic diabetes and the chance observation that 

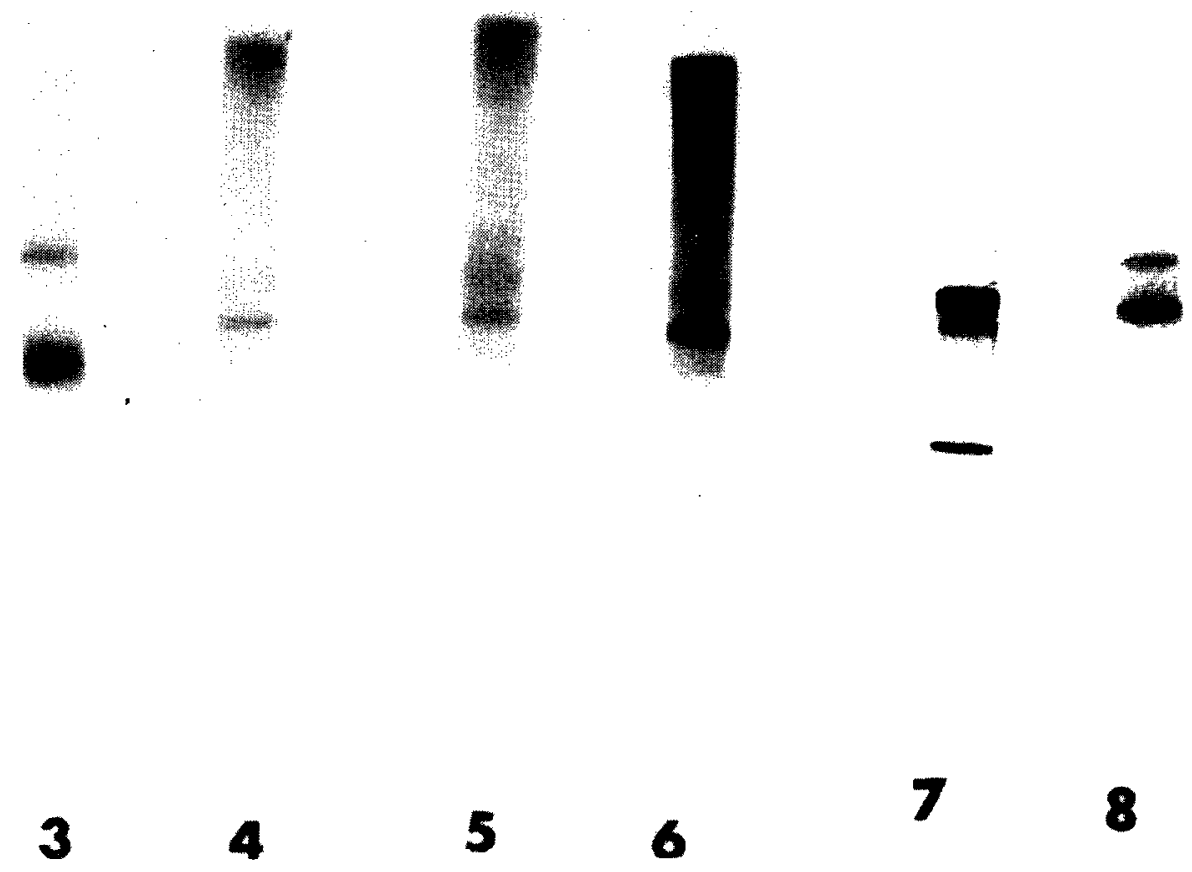

Fig. 4

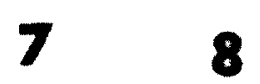

Fig. 5

it was present in a proteinuric maturity-onset diabetic, we have been seeking to find the material in other diabetic patients. The significance of the associated proteinuria was not appreciated initially. It is now apparent that the peptide was present in the urine of 33 of the 35 diabetics with proteinuria but was present neither in 32 nonproteinuric diabetics nor in 34 healthy subjects. In 1 of 7 nondiabetics with proteinuria, a small amount of material which precipitated at $\mathrm{pH} 4.1$ was found but it was insufficient to test for biological activity. When the material is present in proteinuric urine, it is not related quantitatively to the amount of protein excreted. Nineteen $(58 \%)$ of the 33 patients excreting this peptide had detectable diabetic retinopathy of various grades and it is evident that all had some form of nephropathy. The observation that the diabetogenic peptide disappeared from the urine following hypophysectomy in the one such case in which it was studied, together with our ability to isolate a similar material from the adenohypophysis of beef, sheep, and swine, suggests that it originates in the pituitary gland. It is tempting to suggest that this material might somehow be involved in the microangiopathy of diabetes mellitus. In recent studies with frozen human pituitary glands, we have succeeded in isolating a polypeptide (isoelectric point approximately $\mathrm{pH} 4.1$ ) which closely resembles the substance isolated from the urine of patients with proteinuria and diabetes mellitus. These studies will be detailed in another communication.

\section{ACKNOWLEDGMENTS}

The authors are very grateful to Mrs. Sendy Su and Miss Carol Spooner for their expert technical assistance in various aspects of this work and wish to thank the National Pituitary Agency for the frozen human pituitary glands used in this study. 


\section{REFERENCES}

1. Louis, L. H., Conn, J. W., and Minick, M. C.: Lipoatrophic diabetes: Isolation and characterization of an insulin antagonist from urine. Metabolism 12:867, 1963.

2. Hipolito-Reis, C., Sobrinho-Simoes, M., Ferraz, A., Jr., Hargreaves, M. P., and Cerqueira-Magro, F.: Peptide Urinaire de Type Anti-Insulinique dans le Diabéte Dit Lipo-atrophique de Lawrence. Rev. Franc. Endocr. Clin. 9:373-380, 1968.

3. Louis, L. H.: Lipoatrophic diabetes: An improved procedure for the isolation and purification of a diabetogenic polypeptide from urine. Metabolism 18:545-555, 1969.
4. Somogyi, M.: Notes on sugar determination. J. Biol. Chem. 195:19, 1952.

5. Ornstein, L., and Davis, B. J.: Disc Electrophoresis. Rochester, N. Y., Distillation Products Industries, 1958.

6. Louis, L. H., Conn, J. W., and Minick, M. C.: A diabetogenic polypeptide from bovine adenohypophysis similar to that excreted in lipoatrophic diabetes. Metabolism 15:308, 1966.

7. -, and Conn, I. W.: A diabetogenic polypeptide from hog and sheep adenohypophysis similar to that found in lipoatrophic diabetes. Metabolism 17:475, 1968. 